\title{
Shakespeare on the Page in Romania: Before and After 1989
}

\author{
George Volceanov
}

\begin{abstract}
This article aims to identify the evolution of Shakespeare's reception in Romania - not as a powerful icon of world drama, i.e., not from the viewpoint of performance criticism, but as the subject of reference books written in Romania in the Communist and the post-Communist age, respectively. The history of Shakespeare monographs and collective volumes produced in the interval examined here has three distinct phases: (1) the first, spanning from 1945 to 1965, reveals the strong influence of Russian Bolshevik ideology; (2) in the second phase, overlapping Nicolae Ceauşescu's national-Communist dictatorship, Shakespearean criticism, paradoxically, appears to be freed from the impositions of Communist ideology; (3) the postCommunist decades witness the emergence of at least two generations of Shakespeare scholars who write mostly in English, either for a foreign readership (participating in the newly developed cultural exchanges of the 'global village') or for Romanian readers that are speakers of English - hence, a gap appears between the works of local Shakespeare scholars and the national culture.
\end{abstract}

\section{Key words}

Shakespeare, book, Communist ideology, global village, national culture 


\section{5-1965}

Shakespeare's reception and internalisation in Romania unfolded, like everywhere else, via two media, namely, the stage and the page. The more than two-century-long history of acculturation by means of translations and theatrical productions has received due attention from Romanian scholars, especially after 1989. Outstanding monographs have been devoted to this issue (see MATEI-CHESNOIU 2006, 2009; CINPOEŞ 2010). With more than four hundred productions staged in the past seven decades, Shakespeare has been a strong presence on Romanian stages. While Shakespeare's Romanian translations and Romanian stage history have been thoroughly scrutinised in recent years by more than one generation of Shakespeare scholars, less attention has been devoted to the books written about Shakespeare and to the way in which these books contributed to the construction of a cultural icon suitable for the historical context(s) and political situation(s) that engendered it. That is why what I focus on in this article is Shakespeare on the page. This text may be construed as a survey, review, and inventory of writings dedicated to various aspects of Shakespeare's works before and after the fall of Communism in Romania.

Communism in Romania had two distinct phases: (1) the first, spanning from 1945 to 1965, reveals the strong influence of Soviet Bolshevik ideology imposed with the aid of the Red Army stationed in Central and Eastern European countries (the Soviet army withdrew from Romania as late as August 1958); (2) the second phase coincides with Nicolae Ceaussescu's national-Communist dictatorship, spanning from 1965 to 1989.

In Romania, similarly to all the Soviet-occupied countries, the first years of imported Communism saw the imposition of social realism and of the task of 'forging the new man' in the light of a resolution adopted on 26 August 1946 by the Central Committee of the Communist Party of the Soviet Union (GUNTNER 2001: 31). A cursory look at the way political and educational institutions in the Communist satellite-countries capitalised on bringing Shakespeare to the foreground of their cultural life will reveal that his appropriation evolved everywhere quite along the same lines. Let us take a look at an excerpt from a Polish textbook issued in the early $1950 \mathrm{~s}$, which, quoting an interpretation by M. Morozov, reduces The Tempest to a 'hymn celebrating humanity and its happy prospects', as well as 'the human victory over nature and the eminent triumph of the positive element over the bestial', a play in which 'the mature wisdom of Prospero paves the way towards happiness for the young generation' (CETERA 2014: 132-133). The same type of discourse dominates the cultural manifesto titled 'Shakespeare, realist and humanist, genius of world literature', broadcast in April 1964, in which the East German minister of culture Alexander Abusch contended that Shakespeare's humanism and realism anticipated, in fact, the Socialist culture of the 1960s (GUNTNER 2001: 35-36). And still the same spirit of the age resonates in a Romanian handbook of world literature for eleventh grade high school students, in the gobbledygook of the 1960s: 
Shakespeare's great tragedies originated in a feeling of great disappointment when the playwright, alongside other illustrious writers of the late Renaissance, could clearly see that the new-born society had started to bring down the edifice of the unfair feudal world only to have it replaced by an even more unfair world based on the worship of money, of treacherous and ferocious egotism. However, his love for people and his great belief in man's moral virtues prevented him from plunging into the abyss of despair. That is why, even in his great tragedies, man triumphs over evil. ${ }^{1}$ (BARBU et al. 1967: 84)

Dissident attitudes were harshly punished throughout the Communist bloc: writers, translators, and directors were banned or sent to work in mines and factories. In East Germany, director Adolf Dresen was 'sent off' by the East German authorities to 'an oil refinery in Greifswald to learn from the working class' for a bold staging of Hamlet back in 1964 (DRESEN 2001: 152). Dan Duțescu, one of the all-time best Romanian translators, had incidentally been the private secretary of the Communist leader Lucrețiu Pătrăşcanu, who had been executed after a frame-up trial in 1953 at the order of the authoritarian party leader Gheorghiu-Dej. As a penalty for his past connections, Duțescu was kept unemployed for nearly a decade and he had to spend two years working in a factory before being at long last admitted to the staff of the English Department of the University of Bucharest. Conversely, apparatchiks enjoyed the favours of the Communist regime.

The flip side of the coin was the promotion of the supporters and ideologues of the Communist regime. In Czechoslovakia, the 'politically agile manipulator' Erik Adolf Saudek 'managed almost to eradicate all his translator rivals' and his 'choices of what to translate dictated what is to be performed on the Czech stage' (DRÁBEK 2014: 68).

In the late 1940s, he was a fervent supporter of the Communist Party (took part in meetings, etc.). In 1949, as a dramaturg of the National Theatre, he staged not only his own translations but also agitprop plays. Although he did not hold any 'official' political function, he had a monopoly on Shakespeare on stage. [...] Saudek was the most frequently staged translator until the 1980s. (MIŠTEROVÁ 2020)

Saudek's position is closely mirrored by Mihnea Gheorghiu's career in Romania. Gheorghiu was one of the most talented participants in the state-sponsored project of the first Romanian edition of Shakespeare's Complete Works; he was a poet, playwright, novelist, literary critic, and ... apparatchik, appointed vice-president of the State Committee for Culture and the Arts, vice-president of the Romanian Institute for Cultural Relations with Foreign Countries, and president of the Romanian Film Artists' Union.

Gheorghiu translated no more than four plays by Shakespeare and yet his translations were staged ten times as often as those of his fellow-translators: given his privileged position, Gheorghiu was likely able to influence the choice of repertoire in 
theatres, or, at least, ingratiating directors and theatre managers could pay lip service to him. Gheorghiu's career is reminiscent not only of Saudek's but also of the Slovak Jozef Kot's, who, 'based on his high political position, was the chief authority to all the publishers and theatres alike and placed his Shakespeare in both of these two households' (BŽOCHOVÁ-WILD 2014: 90).

Back to Shakespeare on the page in Romania, it was Gheorghiu who wrote the first influential book in which Shakespeare was Sovietised and used as an asset in the ideological war waged against capitalism and Western values. Gheorghiu reinvented a neatly censored Shakespeare as a working-class hero, a great patriot, and a true example of what a family man is. His book Scene din viața lui Shakespeare [Scenes from Shakespeare's Life] was first published in 1958, with massive reprints following in 1964 and 1968. Gheorghiu's Shakespeare was a diligent, patriotic, thrifty protoCommunist with a deep concern for the past misfortunes and the future welfare of his people and of mankind in general. Shakespeare's lower (or, to use a Communist cliché, 'sound') social origins were emphasised to the detriment of his impressive ancestry on his mother's side. Gheorghiu's Shakespeare implicitly endorsed the view that any low-born rustic without much learning but endowed with an industrious and enthusiastic spirit could earn fame and acquire a good job. This 'popular' version of the Elizabethan playwright was fabricated in the heyday of the so-called popular schools of literature, which were replicating this Shakespeare by the dozens, cloning mini-Shakespeares eager to write the true chronicle of a 'Merry Romania' in the name of Socialist realism. In Gheorghiu's opinion, Shakespeare's main concerns were the never-ending class struggle, the decline and fall of feudalism, and the young generation's hope for a better future. In his translation of King Lear, issued in several editions, Gheorghiu echoes Morozov's promised 'happiness for the young generation' (CETERA 2014: 133). The gloomy prediction of the final couplet 'The oldest hath borne most: we that are young / Shall never see so much, nor live so long' (King Lear 5.3.318-319) is rendered, in Romanian, as 'Bătrânii-au suferit să te cutremuri. / Noi, tinerii, trăi-vom altă viață' (SHAKESPEARE 2016: 942), i.e., 'The old have suffered a lot. / We, the young ones, will live a different life.' Shakespeare makes it clear that the young characters are doomed to live a short life, but his statement is supplanted by the bright future promised by Communist propaganda.

The period 1945-1965 is marked by a scarce output of critical works dedicated to Shakespeare and by the mandatory citing of Russian and Soviet critics such as Chernyshevsky, Belinsky, Anikst, etc. Apart from being used for the advancement of the Socialist education of the masses in the 1950s and the early 1960s, Shakespeare did not elicit an extraordinary response among Romanian academics; few of them could truly call themselves Shakespeare scholars. Only three more titles can be added to Gheorghiu's aforementioned Shakespeare biography: a collection of excerpts from essays by authors from all ages and from all over the world titled Shakespeare si opera lui: culegere de texte critice [Shakespeare and His Work: A Collection of Critical Texts], a bilingual anthology of Shakespearean texts selected and edited by Leon Levițchi and Dan Duțescu (1964); and Alexandru Duțu's Shakespeare in Romania: A Bibliographical Essay 
(written in English, 1964), all of these texts commissioned by the authorities on the occasion of the $400^{\text {th }}$ anniversary of Shakespeare's birthday. ${ }^{2}$

The eleven-volume first edition of Shakespeare's Opere/Works (issued between 1955 and 1963), the so-called ESPLA edition, compensated for the lack of original Shakespeare criticism. Even so, it was almost completely devoid of scholarly interpretation, except for a thirty-five page Introduction written by the same translator, scholar, and apparatchik Mihnea Gheorghiu (1955), a text peppered with quotes from Marx, Engels, and Lenin. G. Wilson Knight and Ivor Brown were the only Western critics mentioned, only to be refuted with the arguments borrowed from V. Uzin, an obscure, now-forgotten Soviet scholar.

\section{5-1989}

Nicolae Ceaussescu became General Secretary of the Romanian Communist Party in 1965. His refusal to have Romania participate in the invasion of Czechoslovakia in 1968, alongside the other country-members of the Warsaw Treaty, turned him into an international hero praised by the West. The benign attitude of the West to him enabled Ceauşescu to launch a new trend in Romanian politics and to inaugurate his national-Communist dictatorship. After a six-year period of relaxation, during which literature and the arts regained partial freedom of expression, in his infamous 'July Theses' launched on 6 July 1971 in the wake of his visits to China and North Korea, Ceauşescu tightened his grip on education, culture, and the media. He demanded that the artists' unions should promote revolutionary ideas in their works, reflect the aspirations and achievements of the people, and emphasise the 'positive' aspects of what was, in fact, an oppressive regime aimed at forging an illusory 'new man'. The 'cultural revolution' initiated by the July Theses, while claiming to promote 'Socialist humanism' marked a return to the strict guidelines of the earlier Socialist realism. Ceaussescu used all available resources to promote the cult of his personality. The dictator's harsh impositions engendered several unexpected paradoxes. Criticising the present-day reality was banned, but writers were permitted, even encouraged, to debunk the errors of the Stalinist age as well as of Ceaussescu's Communist precursors. Hence a long series of best-sellers followed in which outstanding novelists dealt with the so-called 'obsessive decade' (1950-1960); in order to avoid censorship, Romanian pop/rock/folk musicians chose to use, instead of original lyrics (which were censored more often than not), poems by canonical, classical, or contemporary poets; conversely, Radio Romania kept incessantly broadcasting the anthems of the flower power generation (San Francisco, Those Were the Days) although in the Romanian literature of the 1960s and the 1970s 'negative' young characters were usually portrayed and branded as beatles (sic) or hippies (VOLCEANOV 2013).

2 The confines of this article do not allow me to include all the listed titles in the bibliography. I shall list under the heading Bibliography only the actual sources cited or those that played a significant part in the reception of Shakespeare in Romania. 
In 1969, in an atmosphere of optimism and relaxation, Jan Kott's Shakespeare, Our Contemporary was first issued in Romania. It remains to this day the best-known reference work on Shakespeare, with the highest print run in the field of Shakespeare studies. Curiously, notwithstanding the numerous strictures imposed by party documents and censorship, Romanian scholars could now enjoy relative freedom in that they no longer had to pay lip service to Soviet literary criticism. Moreover, Shakespeare studies allowed scholars to avoid the usual flattering the dictator craved for.

The 1970s signal a turning point as regards the original contribution of Romanian scholars to Shakespeare studies. Dan Grigorescu, the author of Shakespeare in cultura română [Shakespeare in Romanian Culture] (1971) and Aurel Curtui, the author of Hamlet in România (1977) produced trendsetting monographs that paved the way for subsequent research in the history of Shakespeare's reception in Romania.

In 1976, Leon Levițchi collected the articles he had previously published in philological journals in the 1950s and 1960s, at the height of Socialist realism and Soviet propaganda, in a volume simply titled Studii shakespeariene [Shakespearean Studies] (1976). In his approach to Shakespeare's plays, Levițchi applied the methods of formalism, structuralism, and comparative literature and, to his credit, he used a completely depoliticised critical discourse. Levițchi was one of the few Romanian critics to tackle textual issues and to produce original findings. Unlike Levițchi, Dan A. Lăzărescu, notwithstanding his bulky volume Introducere in shakespeareologie [An Introduction to Shakespeareology] (1974), was merely an enthusiast, an amateur both as a scholar and a translator, while Alexandru Olaru was a distinguished psychiatrist with no knowledge of English but with a huge interest in Shakespeare's plays. Olaru wrote yet another fat book, Shakespeare și psihiatria dramatică [Shakespeare and Dramatic Psychiatry] (1977) based on his extensive reading of French sources. The then very young Pia Brînzeu (in Dramatic Art and Technique in Othello, 1978) and Mihai Rădulescu (in Shakespeare - un psiholog modern [Shakespeare - A Modern Psychologist], 1979) approached Shakespeare from a cybernetic and psychological viewpoint, respectively. Brînzeu's approach to Othello, based on game theory and systems theory, was way ahead of its time and is still cited to this date in prestigious Western publications. Rădulescu's study revisited a series of celebrated scenes from Shakespeare's plays, re-reading them as psychological experiments in which some characters act as scientists while others are reduced to the status of guinea pigs. In 1981, Adrian Poruciuc drew a parallel between the Sonnets and Vasile Voiculescu's Ultimele sonete inchipuite ale lui Shakespeare [Shakespeare's Last Imaginary Poems] in a comparative study titled Structuri dramatice si imagini poetice la Shakespeare şi Voiculescu [Basic Dramatic Structures and Imagery in Shakespeare and Voiculescu] which was reprinted in 2001.

Ion Omescu (1925-2002), an actor, director, and scholar, is a fascinating figure who managed to survive many years of persecution for his sexual orientation (especially in the late 1940s and in the 1950s). He wrote an important essay on Hamlet in 1971 ('Hamlet sau ispita posibilului' [Hamlet or the Temptation of the Possible]), and when he was invited to Stratford-upon-Avon in 1972, he used this opportunity to defect. After settling down in Paris, Omescu earned a Ph.D. degree at the University of Paris VII 
in 1974. He authored several books on Shakespeare, taught drama in Belgium and the Netherlands, worked for the BBC, and founded a theatre company. Years later he revised his book on Hamlet, and its updated French version issued in 1987 won the French Academy Biguet Award. In Romania, a second edition was issued during the International Shakespeare Festival held in Craiova in 2010, but Omescu's overall contribution to Shakespeare studies is still waiting to be discovered by the younger generation of Romanian scholars.

A book that passed almost unnoticed in its days was Aureliu Manea's Spectacole imaginare [Imaginary Performances] (1986). While writing this article I received the following online blurb from Michael Dobson, the director of the Shakespeare Institute at the University of Birmingham:

Aureliu Manea (1945-2014) was one of the visionaries of the post-war Romanian theatre. Imaginary Performances, his meditations on nineteen of Shakespeare's plays [...], is now made available in English for the first time. Although over the course of his career Manea worked across a broad range of classic scripts - from Sophocles through Chekhov and beyond - his first love remained Shakespeare. His productions of Macbeth and Twelfth Night are legendary: Imaginary Performances offers tantalizing glimpses of further Shakespearean productions which might have been, each one designed less to explain a Shakespeare play than to at once fathom and honour its mystery. (SOCIETY 2020)

The gloomiest decade of Ceauşescu's dictatorship paradoxically witnessed the issue of Romania's second edition of Shakespeare's complete Works. As editor, Leon Levițchi could assert his intellectual freedom in his vast commentaries accompanying the translations, commentaries which drew on state-of-the-art Shakespeare criticism, relying on the Arden Shakespeare and the Macmillan Casebook series. According to a recent study,

it is difficult to find, in this text, any ideological comment or submission to political requirements. The published text demonstrates an openness towards foreign criticism without fear of presenting controversial ideas about Shakespeare that are not included in any of the prefaces previously published. Though still remaining a cultural icon, Shakespeare is presented here as a more complex personality and his life and work are not meant to serve any Communist propagandistic purposes. (MILICĂ 2012: 35)

\section{0 - to the present}

The fall of Communism in Central and Eastern Europe coincided with the burgeoning of Neo-Marxism and Cultural Materialism in the West (see, for instance the Alternative Shakespeares series) and concerted efforts to decentralise the Western canon and debunk Shakespeare as a cultural icon. There was a time when Charles Marowitz could argue that 'there is very little compulsion' behind the academic kind of Shakespeare 
scholarship 'other than scoring points or sticking feathers in one's cap'. He called it 'harlotry in bardolatry' (MAROWITZ 1988: 3). But the truth is that things had already changed a lot in the Western academia, with Shakespeare being 'no longer one of the top 25 authors listed by the U.S. National Association of Scholars. Shakespeare has lost ground along with Milton, Blake, Wordsworth, Eliot, Hardy, Spenser, Keats, Byron, and Coleridge' (CUNNINGHAM 2002: 46), hence Harold Bloom's fierce response against the School of Resentment. ${ }^{3}$

Unlike the well-paid Western academics who tried hard to displace Shakespeare from the canon, Central and Eastern European academics and men of theatre, at long last freed from the impositions of Communist ideology and censorship, could revisit Shakespeare's work, reinterpret it freely and stage it in an innovative style. Viewed from the West, things seem to go against the grain in this part of Europe, as here Shakespeare studies have gained more and more ground in academia. There are many doctoral schools training students to become Shakespeare experts and to write books about his work. Romania is just one of the ex-Communist countries that have hosted several international events dedicated to Shakespeare and have had several Shakespeare research projects funded. The confines of this article allow me to list randomly only a few titles and editors of volumes published in the aftermath of these projects: Shakespeare in the Romanian Cultural Memory: A Model of European Cultural Integration (Monica Matei-Chesnoiu, 2006-2008); (In)Hospitable Translations: Fidelities, Betrayals, Rewritings (Mădălina Nicolaescu and Sorana Corneanu, eds., 2010); Shakespeare in Europe: Nations and Boundaries (Odette Blumenfeld and Veronica Popescu, eds., 2011); Shakespeare, Translation and the European Dimension (Mădălina Nicolaescu et al., eds., 2012); Shakespeare 400 in Romania (Mădălina Nicolaescu et al., eds., 2016); Shakespeare in Romania, Shakespeare in the World (Ioan Cristescu and George Volceanov, eds., 2017), and, most recently, Perspectives on Shakespeare in Europe's Borderlands (Mădălina Nicolaescu et al., eds., 2020).

The emergence of several doctoral programmes in Romania in the $21^{\text {st }}$ century ensured the rise of a new generation of Shakespeare scholars. More than thirty doctoral theses about Shakespeare have been defended in the past two decades. ${ }^{4}$ The West University of Timissoara produced five Ph.D. theses between 2005 and 2016. Their topics varied from representations of woman's body in a patriarchal world to legal issues in the comedies, Marina Warner's rewriting of The Tempest, Shakespeare's impact on the Pre-Raphaelite Brotherhood, and yet another anatomical topic, namely, blood as a symbol and a vital fluid. Two of the five theses have been published so far.

Craiova, the hometown of an important Shakespeare Festival, has produced nine Ph.D. theses on Shakespeare in just one decade. Their themes, vast and varied as well, cover

3 Marowitz (1988) is right when he claims that the Shakespeare industry of conferences, books, periodicals, festivals, indeed provided well-paid jobs, academic degrees, and so on; he only forgets that it was the pack of radicals engaged in debunking Shakespeare, Marowitz himself included, that mostly benefited from that industry.

4 I would like to express my gratitude to fellow-Shakespeareans Monica Matei-Chesnoiu, Mădălina Nicolaescu, Pia Brînzeu, Andreea Șerban, Emil Sîrbulescu, Iulia Milică, and Codrin Liviu Cuțitaru for the data and statistics referring to Romanian doctoral programmes and their Shakespearean output. 
feminist issues, theories of identity, the poetic geography of the Mediterranean, politeness strategies in the poems, the reception of Shakespeare in the Arab world, a comparative study in Shakespeare and Cervantes, adaptation studies and, last but not least, the mechanism of the triple revenge in Hamlet. Three of the nine theses have been published to date.

The five Ph.D. theses written in Iaşi, the city where the European Shakespeare Research Association was founded in 2007, range in their interests from translation studies and the reception of Shakespeare in Romania to comparative literature and the morals and ethics of Shakespearean characters. None of these theses has been published; however, academics based in Iaşi have written three monographs and edited two collective volumes on Shakespeare in recent years.

Monica Matei-Chesnoiu, head of the doctoral school in Constanța, the author of $R e^{-}$ imagining European Western Geography in English Renaissance Drama (2012), has recently supervised two theses: one dedicated to Ovid's mythology and topography in early modern drama, the other to the comparison of English Renaissance translations with nineteenth-century Romanian translations. Both theses have been recently published.

Mădălina Nicolaescu's doctoral students in Bucharest have followed in the steps of their mentor and focused mostly on the history of Shakespeare's reception in Romania. Oana Alis Zaharia is now an expert in nineteenth-century Romanian translations and adaptations of Shakespeare's plays, while Viviana Iacob, the author of Shakespeare Productions: A Study in the Socialist Realism in the Romanian Theatre (1946-1964), has become the leading authority on Shakespeare performed according to the strictures of Socialist realism.

Two outstanding doctoral theses (one by Dana Monah, on French adaptations of Richard III, the other by Anca-Simina Marin, on the Romanian translation of Shakespeare's puns) have been supervised by George Banu (Paris) and Kirk Delabastita (Namur). Both theses await publication. At this moment it is hard to decide whether Nicoleta Cinpoess and Lucian Ghita (active in Worcester, UK, and Clemson, South Carolina, respectively) still belong to the Romanian academic establishment or to their Western milieu.

All in all, Shakespeare studies have flourished in Romania after the fall of Communism and the Iron Curtain. Three successive generations of scholars have engaged in keeping the interest in Shakespeare's works alive. What these generations really lack is visibility in their native culture. Their work is written solely in English and their virtual beneficiaries are English-speaking academic communities, not the Romanian general public and Romanian-speaking readers. Dozens of monographs on Shakespeare have appeared in the last twenty to thirty years, dealing with history of reception, performance criticism, feminism, deconstruction, translation studies, stage history, and so on. All of these books are written in English. The few ones written in Romanian after 1990 are the output of amateur non-philologists: they do not reflect the actual standards of local Shakespeare studies. Emil Lungeanu's two books, Fantoma Shakespeare [Shakespeare, the Ghost] (2010) and Anonimul Shakespeare [The Anonymous Shakespeare] (2013), advocate Edward de Vere's authorship of Shakespeare's works, 
while Florin Mihăescu's Shakespeare și strategiile însingurării [Shakespeare and Strategies for Solitude] (2001), Shakespeare și teatrul inițiatic [Shakespeare and the Theatre of Initiation] (1998), and Shakespeare și tragediile puterii [Shakespeare and the Tragedies of Power] (2001) are the result of an esoteric approach. Horia Gârbea's Lunaticul, indrăgostitul și poetul sau Despre personajele lui Shakespeare [The Lunatic, the Lover, and the Poet: Essays on Shakespeare's Characters] (2018) is a collection of essays based on a translator's first-hand impressions, and Gelu Ionescu's Cartea lui Prospero [Prospero's Book] (2017) is yet another collection of critical essays written in the vein of early $20^{\text {th }}$-century impressionist criticism.

The real Shakespeare scholars' self-imposed exile from their vernacular along with the publication of these amateurish books serve to create a deceptive reflection of what Romanian Shakespeare studies is today. A notable exception is Dana Percec's The Body's Tale: Some Ado about Shakespearean Identities (English version 2006), which appeared in Romanian translation as well (Despre corp şi ipostazele sale in teatrul shakespearian, 2008). Conversely, Octavian Saiu's Hamlet si nebunia lumii (2014), first issued in Romanian, later appeared in English as well (Hamlet and the Madness of the World, 2016). These two examples only amplify the feeling that Romanian Shakespeare scholars are cut off from Romanian culture, and that this gap needs to be bridged via translations and publications. What bodies will take upon themselves to bridge this gap? The Romanian Cultural Institute? The Academy? Romanian publishing houses? Two forthcoming books due to be issued in the autumn of 2020, both written in Romanian for the benefit of the general readership, Pia Brînzeu's Fantomele lui Shakespeare [Shakespeare's Ghosts] and George Volceanov's Intoarcerea la Marele Will sau Reconsiderarea canonului shakespearian [The Shakespeare Canon Revisited], are just a drop in the ocean when compared with the texts penned in English.

As if, again, to compensate for the meagre output of Shakespeare studies in Romanian, a third, enlarged edition of Shakespeare's Works in sixteen volumes was issued between 2010 and 2019. Its editor is the author of this article. This was the first Romanian edition to include three versions of Hamlet, two versions of King Lear, the recently canonised The Two Noble Kinsmen, Edward III and Sir Thomas More as well as Lewis Theobald's adaptation of the now lost Cardenio (Double Falsehood). Viewed in a wider, European context, it followed the example of Martin Hilskýs Czech edition (1999-2010) and of the more recent Finnish edition (2004-2013). Unlike other European editions, this one did not receive institutional support. It was the result of a private initiative.

A blurb on the jacket of the first volume of the new edition of Shakespeare's Works (2010) claimed that it would modernise the vocabulary of the Romanian versions in order to make them accessible to the new generation of readers and theatregoers. It would do away with the distinction between the seemingly irreconcilable notions of philological and performance-oriented translation; it would de-censor and de-bowdlerise the Shakespearean text; it would bring forth new textual interpretations relying on the latest critical editions (and especially on the Arden Shakespeare series); and it 
would pay due respect to the prose and prosody of the original, i.e., to the principle of stringency. ${ }^{5}$ These guidelines had to be observed by all the translators participating in the project. The norms and strategies of this edition coincidentally resemble those expounded long ago by the Hungarian poet János Arany: for him, too, the translation was 'primarily prepared for the stage', 'for theatre-makers'; it should be 'true to the ideas and the form of the original'; it should not omit 'lewd or obscene passages' and it should render 'an unabridged Shakespeare rather than a purified one' (MINIER 2014: 46-47).

This latest Romanian edition is the result of the joint effort of nine translators. Fifteen academics from eight universities contributed to the editorial material with cutting edge introductions and prefaces. Writing in Romanian, they have had the opportunity to reconnect with a wider readership and to increase their visibility in the local book market. Most of the participants in this editorial venture (five translators and twelve academics) are women, making it a sui generis feminist edition.

Critics have adroitly noticed that 'Volceanov's Shakespeare is, like Gheorghiu's, a Shakespeare of the masses, but the way the former writer addresses these commentators in Romanian is different in the free-of-taboos 2000s than it was in the more conservative 1950s.' Given that this is 'the first attempt to consistently translate slang and indelicate words directly' some academics expressed skepticism 'as to whether the 2000s Romanian Shakespeare will be long-lived, or future translators will return to more conservative methods of rendering Shakespeare's texts into Romanian' (PUNGĂ and PERCEC 2019: 89). Nevertheless, twenty-six productions have used the new translations so far, with the Craiova Shakespeare Festival being in particular the venue that has consistently promoted the new translations.

\section{From Wind of Change to Go West!?}

The data presented so far point to the wider and wider gap between the Romanian Shakespeare scholars' interest(s) and their native readership, and to the way in which this gap might or should be bridged in the future. And this is not a local, isolated phenomenon. Fewer and fewer Central and Eastern European Shakespeare scholars write in their own vernacular. They are active participants in the data exchange of the global village, yet in relation to their national cultures their image wanes; in relation to vernacular readers, they signify a huge absence, a blank page in the culture of their countries. They receive accolades abroad, and their books and articles are printed by prestigious publishers, but 'at home' they are much less visible. Is this a sign that postCommunism has been displaced by a kind of cultural post-colonialism, in which the global supplants the local?

5 This phrase coined by Tieck and Schlegel meant that in translating Shakespeare's plays, the translators committed themselves to render the original blank verse as blank verse, rhymed verse as rhymed verse, and prose as prose. The phrase has more recently been resuscitated and applied to their translations by Angel Luis Pujante and George Volceanov, see (VOLCEANOV 2010: 176-178). 
Today we can apply the phrase translatio imperii to Shakespeare studies, which has come to indicate the migration of Shakespeare scholars from the East to the West. People born in ex-Communist countries are now teaching native Brits and Americans who Shakespeare was, and this is a soothing thought, indeed. Boika Sokolova (Bulgaria) has moved from Sofia to London; speaking of Hungarians, Zoltán Márkus has departed Budapest for Poughkeepsie (Vassar) via Carbondale, and Márta Minier has left Debrecen for Cardiff via Hull; Romania's foremost representatives in the academic migration are Nicoleta Cinpoeș, who has left Suceava for Worcester via Warwick, and Lucian Ghita, who has left Bucharest for Clemson via Yale; Pavel Drábek has likewise left Masaryk University in Brno (Czech Republic) to become a successful drama professor in Hull; Aleksandra Sakowska and Aneta Mancewicz (Poland) are currently affiliated with universities in Birmingham and London, respectively... And one could add many more names to this list.

While many talented Shakespeare scholars have chosen to migrate to the West, it is also true that many of them still act in the interest of their native countries by bridging gaps between Eastern and Central Europe and the Anglophone world. They still play an important role in the numerous international conferences organised in Romania with the frequent participation of great Shakespeare scholars like Stanley Wells, Michael Dobson, Stephen Greenblatt, and Michael Hattaway, among others. Nicoleta Cinpoess, for instance, is the founder of a permanent seminar dedicated to Shakespeare in Performance held every two years under the aegis of the Craiova International Shakespeare Festival. Cinpoeş has greatly increased the prestige of the festival and added lustre to it by shepherding an entire issue of Cahiers Élisabéthains dedicated to the reviews jointly written by the participants in the 'Viewing and Reviewing' seminar held during the 2018 festival.

Shakespeare has acted as a catalyst in Central and Eastern Europe, bringing yet another example of how interest in his works remains in the long run a common denominator of academics, writers, and theatre-people, as well as a perpetual source of creativity and intellectual freedom for all.

\section{Bibliography}

BARBU, N. I. et al. 1967. Istoria literaturii universale [A History of World Literature]. București: Editura Didactică și Pedagogică, 1967.

BRÎNZEU, Pia. 1978. Dramatic Art and Technique in Othello. Timișoara: Editura Universității de Vest, 1978.

BŽOCHOVÁ-WILD, Jana. 2014. 'Now [...] what is your text?' Translating \& Publishing Shakespeare in Slovak. In Jana Bžochová-Wild (ed.). 'In double trust': Shakespeare in Central Europe. Bratislava: Vysoká škola múzických umení, Divadelná fakulta, 2014: 73-102.

CETERA, Anna. 2014. Be Patient till the Last: The Censor's Lesson on Shakespeare. In Jana Bžochová-Wild (ed.). 'In double trust': Shakespeare in Central Europe. Bratislava: Vysoká škola múzických umení, Divadelná fakulta, 2014: 129-150. 
CINPOEȘ, Nicoleta. 2010. Shakespeare's Hamlet in Romania, 1778-2008. Lewiston and New York: Edwin Mellen Press, 2010.

CUNNINGHAM, Valentine. 2002. Reading after Theory. Oxford and Malden: Blackwell, 2002.

DRÁBEK, Pavel. 2014. From the General of the Scottish Army to a Fattish Beer-Drinker: A Short History of Czech Translations of Macbeth. In Jana Bžochová-Wild (ed.). 'In double trust': Shakespeare in Central Europe. Bratislava: Vysoká škola múzických umení, Divadelná fakulta, 2014: 53-72.

DRESEN, Adolf. 2001. The Last Remains of the Public Sphere. In J. Lawrence Guntner and Andrew M. McLean (eds.). Redefining Shakespeare: Literary Theory and Theatre Practice in the German Democratic Republic. Newark and London: University of Delaware Press and Associated University Presses, 2001: 151-162.

GUNTNER, J. Lawrence. 2001. Introduction: Shakespeare in East Germany: Between Appropriation and Deconstruction. In J. Lawrence Guntner and Andrew M. McLean (eds.). Redefining Shakespeare: Literary Theory and Theatre Practice in the German Democratic Republic. Newark and London: University of Delaware Press and Associated University Presses, 2001: 29-57.

MAROWITZ, Charles. 1988. Reconstructing Shakespeare or Harlotry in Bardolatry. Shakespeare Survey 40 (1988): 3-10.

MATEI-CHESNOIU, Monica. 2006. Shakespeare in the Romanian Cultural Memory. Madison: Fairleigh Dickinson University Press, 2006.

MATEI-CHESNOIU, Monica (ed.). 2009. Shakespeare in Romania. Texte 1836-1016 [Shakespeare in Romania. Texts 1836-1916]. București: Editura Academiei Române, 2009.

MILICĂ, Iulia. 2012. William Shakespeare in Communist Romania: Freedom and Limitation in Romanian Editions. Trãduçao em Revista 12 (2012): 18-38.

MINIER, Márta. 2014. Uprooting Shakespeare. A Historical Survey of Early to Institutionalised Hungarian Shakespeare Translation. In Jana Bžochová-Wild (ed.). 'In double trust': Shakespeare in Central Europe. Bratislava: Vysoká škola múzických umení, Divadelná fakulta, 2014: 29-51.

MIŠTEROVA, Ivona. 2020. Personal email correspondence with the author (21. 08. 2020).

PUNGĂ, Loredana and Dana PERCEC. 2019. The Shakespearean Translator - Ariel or Caliban? SKASE Journal of Translation and Interpretation 12 (2019): 2: 83-92. [accessed on 23.01.2021]. Available online at http://www.skase.sk/Volumes/JTI17/pdf_doc/06.pdf.

SHAKESPEARE, William. 2001. King Lear. Ed. by Stanley Wells. Oxford and New York: Oxford University Press, 2001.

SHAKESPEARE, William. 2016. Regele Lear [King Lear]. Transl. by Mihnea Gheorghiu. In William Shakespeare. Opere V. București: Academia Română și Muzeul Național al Literaturii Române, 2016: 747-942.

SOCIETY for Renaissance Studies. 2020. Imaginary Performances in Shakespeare (24. 08. 2020). [accessed on 23.01.2021]. Available online at https://www.rensoc.org.uk/event/imaginaryperformances-in-shakespeare/.

VOLCEANOV, George. 2010. Contending Translations of The Tempest in Present-day Romania. Synergy 6 (2010): 2: 172-188.

VOLCEANOV, George. 2013. Paradoxurile muzicii pop/rock/folk românești din anii comunismului. [The Paradoxes of Pop/Rock/Folk Music in Communist Romania]. Observator cultural 678, (21.06. 2013): 4-5. 


\section{George Volceanov}

Faculty of Letters, Spiru Haret University, 24 Șoseaua Berceni, District 4, 077160 Bucharest, Romania geovolceanov@yahoo.com

George Volceanov is a professor of English Literature at Spiru Haret University, Bucharest, Romania. He is a translator, lexicographer, and the editor of Shakespeare's Complete Works (consisting of entirely new translations), issued in Romania(n) in 16 volumes, between 2010 and 2019. He is the author of three Shakespeare monographs ('Methinks You're Better Spoken': A Study in the Language of Shakespeare's Characters, 2004; The Shakespeare Canon Revisited, 2005; 'The Eye Sees Not Itself but by Reflection': A Study in Shakespeare's Catoptrics, 2006). He has written dozens of articles on Shakespeare's works and he has translated plays by Shakespeare, Thomas Heywood, and John Webster. He has also translated works by David Lodge, Philip Roth, John Updike, Anthony Burgess, Lawrence Durrell, F. Scott Fitzgerald, Truman Capote, Margaret Atwood, Colson Whitehead, and many more. George Volceanov is currently editing a Romanian edition of Christopher Marlowe's Complete Works. 